\title{
MODELLING THE EFFECTS OF RELEASE AND PROPAGATION OF GASES, VAPOURS AND AEROSOLS FROM HAZARDOUS MATERIALS
}

\author{
UDC 620.26
}

\section{Sveta Cvetanović}

\author{
University of Niš, Faculty of Occupational Safety in Niš, Niš, Serbia
}

\begin{abstract}
The effects of release and propagation of gases, vapours and aerosols from hazardous substances are modelled using: ideal models that presuppose that the surface of the horizontal cross section of the container (tank) is constant, that substances are released from the hole in the wall, that the system is not a two-phase system, and that there is no resistance in the discharge; realistic models that take into account the phenomenon of friction; two-phase models that take into account the quality and the specific volume of the mixture of vapour and liquid; and models that take into account the abrupt release of liquids, gases and vapours.
\end{abstract}

Key words: source of hazardous materials, chemical contamination, focal point of accident, chemical accident, estimates and predictions of source parameters

\section{INTRODUCTION}

Dispersion of gases, vapours, and aerosols is performed using models for [9]:

- instant point and volume source - these models model the propagation and diffusion of the primary cloud of vapours and aerosols from hazardous materials, formed due to individual discharge of hazmat vapours;

- instant linear source - these model the propagation and diffusion of the primary cloud of hazmat vapours and aerosols, formed due to a series of discharges along a line that is normal to wind direction;

- continuous point and volume source - these model the effect of a single hazmat liquid discharge, which forms a secondary hazmat vapour cloud due to vaporization;

- continuous linear source - these model the propagation and diffusion of the secondary cloud of hazmat vapours, formed due to vaporization of a series of liquid discharges along a line that is normal to wind direction;

Received February 19, 2020 / Accepted April 23, 2020

Corresponding author: Sveta Cvetanović

Faculty of Occupational Safety in Niš, Čarnojevića 10a, 18000 Niš, Serbia

E-mail: sveta.cvetanovic@znrfak.ni.ac.rs 
- continuous surface source - these model the propagation and diffusion of vapour and aerosol clouds above and near polluted surfaces that emit hazardous materials along the lee side;

- combined source - these involve two or more of the previously described sources.

In a chemical accident zone, depending on the generating conditions and physicochemical properties of toxic compounds, the primary type of contamination occurs due to a release of vapours and aerosols (caused by explosions, fire, free turbulence, or liquid discharge), after which it spreads across a specific distance with the help of meteorological factors (Figure 1) [2].

Chemical contamination, injuries and poisoning of humans can be chronic in nature, stemming from the intake or ingestion of toxic compounds through the respiratory system, the digestive system, the mucous membrane, or the skin.

Chemical contaminants in the atmosphere, soil and buildings are most often undetectable by the human senses. Therefore, detection of contaminants is performed using special devices or visually, and it has to be timely and adequate.

It is very important to know how much time there is left after an accident to identify and collect pertinent data, in order to take proper safety measures and commence with the mitigation.

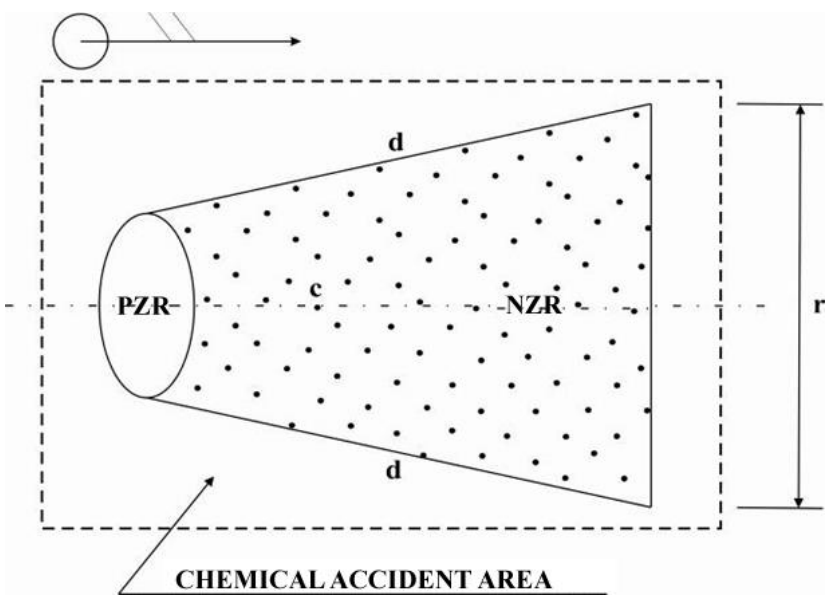

Fig. 1 Schematic of the propagation of chemical contamination: PZR - primary affected area; NZR - subsequently affected area

Hazard detection time $(T)$ is calculated using the following equation:

$$
T=D /\left(V_{V} \cdot 60\right)[\mathrm{min}],
$$

where: $D$ - distance from the accident site $(\mathrm{km}) ; V_{v}$ - speed of the contaminated cloud reaching a specified location $(\mathrm{m} / \mathrm{s})$.

This leads to the conclusion that the time available to alert the population is very short, especially if highly toxic compounds are involved. Chemical safety measures, including the evacuation, need to be taken within the shortest possible period. 
There are multiple ways to calculate safe distances, such as the following:

- semi-empirical approach using the following expression:

$$
L=C^{3} \cdot \sqrt{M},
$$

where: $M$ - mass of chemical substance $(g) ; C$ - constant (depends on the nature of toxic substance); $L$ - hazard radius $(\mathrm{km})$;

- calculation based on Gaussian distribution;

- nomograms designed based on puff models;

- models that calculate safe distances using the OME (Ontario Ministry of Environment) model;

- mathematical model for predicting and assessing contamination atmosphere;

- Slade model for safe distance calculation. This model employs an adequate expression for three states of the atmosphere: neutral (isothermia), unstable (convection) and stable (inversion). The state of the atmosphere is determined according to the coefficient value using the following expression:

$$
e=\frac{D t}{v^{2}},
$$

where: $v$ - wind speed $(\mathrm{m} / \mathrm{s}) ; D t$ - temperature gradient (temperature difference at altitudes of 50 and $200 \mathrm{~cm}$ from the ground); $e$ - degree of vertical air stability in the ground layer.

If the value $e$ is less than -0.1 , the state of the atmosphere is stable; if the values exceed 0.1 , it is unstable; and if values fall within this range, the state is neutral.

The following expression is the calculation of safe distance $h$ according to the Slade model:

$$
h=\frac{2 \cdot C_{h} \cdot B_{h} \cdot 1000}{M_{h} \cdot M_{z} \cdot v \cdot D}[\mathrm{~km}],
$$

where: $C_{h}$ - concentration $\left(\mathrm{mg} / \mathrm{m}^{3}\right) ; B h$ - toxic gas quantity $\left(\mathrm{dm}^{3}\right) ; \mathrm{Mh}, \mathrm{Mz}$ - diffusion coefficients (for air and soil); $v$ - wind speed $(\mathrm{m} / \mathrm{s}) ; D$ - toxic dose $(\mathrm{mg} / \mathrm{kg})$. follows:

The duration of the hazardous effect of primary and secondary clouds is calculated as

$$
T=\left(\frac{L^{2}+8 \cdot K_{0} \cdot t}{v}\right) \cdot 0.5,
$$

where: $v$ - wind speed $(\mathrm{m} / \mathrm{s}) ; T$ - contamination duration $(h) ; L$ - cloud length $(\mathrm{km}) ; K_{0}-$ coefficient; $t$ - time passed from the inception of contamination $(h)$.

The initial data for the assessment and prediction of chemical accidents caused by hazmat accidents include: accident data, information about the units and the population, meteorological conditions, and topographic features of the terrain.

Accident data include: time and place of accident (or armed combat activities/diversions), accident characterization, characteristics of buildings and special accommodation facilities, and properties of hazardous materials. 
Real-time events during hazmat accidents are used to design physical models for accident characterization, whose mathematical characterization defines the mathematical models of the hazmat accident origin and behaviour dynamics.

The focal point of an accident is limited by[1][3]:

- radius $R_{0}$ (of the circle within which the hazmat cloud moves due to gravitational forces and does not obey the laws of turbulent diffusion) and

- diameter of the receiving container (in case of hazmat discharge into the storage tank), or the diameter of the puddle (in case of an accident during hazmat road transport).

Assuming that the primary cloud is formed in the shape of a dome (with the radius equal to height), the radius of the primary cloud base is calculated with the following equation:

$$
R_{0}=\sqrt[3]{\frac{6 V}{4 \pi}}
$$

where: $V$ - volume of hazardous materials in the initial primary cloud, $m^{3}$.

The volume of hazmat primary cloud is calculated as follows:

$$
V=V_{m} \Delta m_{0},
$$

where: $V_{m}$ - specific hazardous material volume $\left(\mathrm{m}^{3} \mathrm{~kg}^{-1}\right) ; \Delta-$ mass fraction of the hazardous material that vaporizes at a specific temperature; $m_{0}$ - total hazmat mass in the $\operatorname{tank}(\mathrm{kg})$.

Specific hazmat volume $V_{m}$ in the vapour phase is calculated as follows:

$$
V_{m}=\frac{22.4}{M} \cdot \frac{T}{T_{0}}
$$

where: $T_{0}$ - absolute temperature at $0{ }^{\circ} \mathrm{C}\left(T_{0}=273.15 \mathrm{~K}\right) ; \mathrm{T}$ - operating temperature, $\mathrm{K}$; $\left(T=273.15+T_{0 C}\right) ; T_{0 C}-$ operating temperature, ${ }^{\circ} C ; M$-molecular mass of the hazardous material.

In the event of combustion or explosion of stored hazardous materials, the affected area becomes home to an extremely hazardous situation, which involves the complex combination of the high temperature of hazardous materials and toxic combustion (or thermal decomposition) products, the shock wave (in an explosion), and other factors.

The 'fireball' dimensions are calculated with the following empirical expression:

$$
R_{0}=27.5 \cdot m^{\frac{1}{3}}
$$

where: $R_{0}$ - 'fireball' radius; $m$ - mass of burnt hazardous material, $t$.

In practice, the radius of $1 \mathrm{~km}$ is adopted as the accident focal point radius in all cases. 


\section{AsSESSMENT OF CHEMICAl ACCIDENT PARAMETERS}

All chemical accident parameters in the propagation zone of the primary and secondary hazmat cloud, which are calculated using the equations presented below, pertain to isothermic conditions.

The depths of primary and secondary cloud propagation are calculated approximately: in case of convection, by dividing the parameters for isothermia by 2 (two); in case of inversion, by multiplying the parameters for isothermia by 2 (two).

The approximate degree of hazmat vapour contamination hazard due to chemical discharges under various conditions can be assessed based on the model of statistical theory, using the expressions obtained as approximate solutions to the turbulent diffusion equation [8][9].

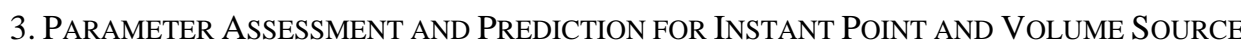

The equation for calculating concentration $C_{x}$, expressed in $m g \mathrm{~m}^{-3}$, originating at ground level and with windward direction (along the $h$-axis), can be expressed as follows[4][5][6][9]:

$$
C_{x} \approx \frac{\Delta m_{0}}{x^{1.75}}
$$

where: $x$-distance from contamination source, $m ; m_{0}$ - total hazmat mass inside the tank $m g$.

The equation was obtained by applying the similarity theory to the confirmed functional dependence of the hazmat concentration change in the ground layer of the atmosphere, according to experimentally verified Roberts' equation - concentration changes with distance according to the following law:

$$
C \approx x^{1,8} .
$$

In case of convection, hazmat concentration is calculated using the following equation:

$$
C_{x} \approx \frac{\Delta m_{0}}{(2 x)^{1,75}} .
$$

In case of inversion, the equation is

$$
C_{x} \approx \frac{\Delta m_{0}}{(0.5 x)^{1.75}}
$$

Toxidosis is a quantitative property of the toxicity of a specific toxic substance, which corresponds to a specific contamination (or poisoning) effect. During inhalation exposure, it represents the product $\overline{C_{t}}$, where $\bar{C}$ is the mean hazmat concentration in the air, $m g m^{-3}$. The received inhalation dose $\left(D_{i x}\right)$ during the exposure of unprotected people to the primary hazmat vapour cloud is described with the following equation: 


$$
D_{i x} \approx \frac{\Delta m_{0}}{x^{1.75}} t,
$$

where: $t$ - time of exposure of unprotected people to the primary hazmat vapour cloud, $s$; $\Delta m$ - mass fraction of the hazmat vapour phase.

Maximum time of hazmat clouds effect on the population $\left(t_{\max }\right)$ is described by the following approximate equation:

$$
t_{\max } \approx \frac{\sigma x_{0}}{V} t,
$$

where: $\sigma x_{0}$ - initial dimensions of the primary hazmat vapour cloud with windward ( $h$-axis) direction (length of the base of the initial primary cloud), $m ; v-$ mean wind speed, $m s^{-1}$.

The time of primary hazmat vapour cloud effect for the instant point source is

$$
0<t \leq t_{\max }
$$

Distance $h$, at which unprotected population can receive the given inhalation dose $D_{i x}$ for the duration of exposure to hazmat cloud $t<t_{\max }$, can be approximately calculated as follows:

$$
x \approx\left(\frac{\Delta m_{0} t}{D_{i x}}\right)^{0.57} .
$$

The depth of primary hazmat vapour cloud propagation $\left(L_{l}, m\right)$ is the distance from the point of origin of the primary cloud to the location where the unprotected population will receive the inhalation threshold dose $\left(P C t_{50}\right)$ during exposure, and it is calculated as follows:

$$
L_{1} \approx\left(\frac{\Delta m_{0} \sigma x_{0}}{v P C t_{50}}\right)^{0.57} .
$$

\section{PARAMETER ASSESSMENT AND PREDICTION FOR INSTANT LINEAR SOURCE}

The equation for calculating concentration $\left(C_{x}\right)$ in windward direction, at ground level, and for a series of instant sources formed along the line normal to wind direction, can be expressed as follows[4][5][6][9]:

$$
C_{x} \approx \frac{20 \Delta m_{0} N}{\sigma y_{0} x^{2}},
$$

where: $N$ - number of tanks containing a hazardous material; $\sigma y_{0}-$ initial dimension of the primary hazmat vapour cloud in the direction normal to that of the wind (width of the base of the initial primary cloud), $m$. 
The inhalation dose received $D_{i x}$ during unprotected population's exposure to the primary cloud is calculated as follows:

$$
D_{i x} \approx \frac{20 \Delta m_{0} N}{\sigma y_{0} x^{2}} t
$$

Distance $h$, at which unprotected population can receive the given inhalation dose $D_{i x}$ for the duration of exposure to hazmat cloud $t<t_{\max }$, can be approximately calculated as follows:

$$
x \approx 28 \cdot\left(\frac{N \Delta m_{0}}{v \sigma y_{0} D_{i x}} t\right)^{0.5} .
$$

The depth of primary hazmat vapour cloud propagation $\left(L_{l}, m\right)$ is the distance from the point of origin of the primary cloud to the location where the unprotected population will receive the inhalation threshold dose $\left(P C t_{50}\right)$ during exposure, and it is calculated as follows:

$$
L_{1} \approx 28 \cdot\left(\frac{N \Delta m_{0}}{v \sigma y_{0} P C t_{50}} t\right)^{0.5}
$$

Owing to a possibility of fluctuating meteorological factors during the diffusion of hazardous vapours and the development of unfavourable situations, a safety correction factor is introduced for practical calculations, so the depth of primary cloud propagation is $\left(L_{1}+1\right) \mathrm{km}$.

\section{PARAMETER AsSESSMENT AND PREDICTION FOR CONTINUOUS POINT SOURCE}

The equation for calculating concentration $C_{x}$, originating at ground level and with windward direction (along the $h$-axis), can be represented as follows[4][5][6][9]:

$$
C_{x} \approx \frac{25 \dot{m}}{v x^{1.8}}
$$

where: $\dot{m}-$ rate of vaporization (contamination source capacity), $m g s^{-1}$ :

$$
\dot{m}=\frac{(1-\Delta) m_{0}}{t_{r}},
$$

where: $t_{r}$ - time of continuous activity of the contamination source, $s$.

Vaporization of discharged hazardous materials creates a secondary hazmat cloud. The vaporization rate of the released hazardous material $\left(\mathrm{mg} \mathrm{s}^{-1}\right)$ can be calculated as follows:

$$
\dot{m}=7.62 \cdot 10^{-4} \cdot(1+2.24 v) \cdot M \cdot S \cdot p^{*},
$$

where: $S$ - surface area of hazardous material vaporization, $m^{2} ; M$ - molecular mass of the hazardous material, $\mathrm{g} / \mathrm{mol} ; \mathrm{p}^{*}$ - hazardous vapour pressure at $20^{\circ} \mathrm{C}, \mathrm{Pa}$. 
Depending on whether the hazardous material is discharged into a safety pool under controlled conditions or it is uncontrollably discharged into the environment during transport, the vaporization surface area $S$ is also calculated. In the former case, vaporization area is the difference between the pool surface area and the tank base. In practice, the area of the safety pool is calculated by dividing the volume of discharged liquid $\left(\mathrm{m}^{3}\right)$ by the height of the discharged liquid column (1.5 $\mathrm{m}$ is the usually adopted height):

$$
S=\frac{m_{0}}{\rho_{t} h_{1}}
$$

where: $t$-density of the hazardous material liquid phase, $\mathrm{kg} \mathrm{m}^{-3} ; h_{l}$ - height of the liquid layer in the safety pool, $m ; m_{0} / \rho_{t}=V_{0}$-volume of discharged liquid, $m^{3}$.

In the event of uncontrolled hazardous material discharge during transport, a hazardous puddle forms on the surrounding land (asphalt, concrete or other base). For practical calculation, the mean puddle thickness of maximum $0.05 \mathrm{~m}$ is adopted:

$$
S=\frac{(1-\Delta) m_{0}}{\rho_{t} h_{1}},
$$

where: $h_{l}$ - liquid layer thickness in the formed puddle, $m$.

The accident focal point radius is calculated with the following equation:

$$
R_{z a r}=\sqrt{\frac{S}{\pi}} .
$$

The inhalation dose $\left(D_{i x}\right)$ received during unprotected population's exposure to the hazmat vapour cloud is calculated as follows:

$$
D_{i x} \approx \frac{25 \dot{m}}{v x^{1.8}} t
$$

Distance $h$, at which unprotected population can receive the given inhalation dose $D_{i x}$ for the duration of exposure to hazmat cloud $t<t_{\max }$, can be approximately calculated as follows:

$$
x \approx\left(\frac{25 \dot{m} t}{v D_{i x}}\right)^{0.55} .
$$

The depth of secondary hazmat vapour cloud propagation $\left(L_{2}, m\right)$ is the distance from the point of origin of the primary cloud to the location where the unprotected population will receive the inhalation threshold dose $\left(P C t_{50}\right)$ during exposure, and it is calculated as follows:

$$
L_{2} \approx\left(\frac{25 \dot{m} t_{r}}{v P C t_{50}}\right)^{0.55},
$$

where: $P C t_{50}-$ threshold dose value; $t_{r}$ - activity period of the contamination source, $s$. 
Owing to a possibility of fluctuating meteorological factors during the diffusion of hazardous vapours and the development of unfavourable situations, a safety correction factor is introduced for practical calculations, so the depth of primary cloud propagation is $\left(L_{2}+1\right) \mathrm{km}$.

\section{PARAMETER ASSESSMENT AND PREDICTION FOR CONTINUOUS LiNEAR SOURCE}

The equation for calculating concentration $\left(C_{x}\right)$ in windward direction, at ground level, and for a series of continuous sources formed along the line normal to wind direction, can be expressed as follows [4][5][6][9]:

$$
C_{x} \approx \frac{25 \dot{m}_{L}}{v x^{0.88}},
$$

where: $\dot{m}_{L}$ - specific capacity of the source, $\mathrm{mg} \mathrm{m}^{-1} \mathrm{~s}^{-4}$ (vaporization rate across the width of the initial contamination cloud's propagation range).

The inhalation dose $\left(D_{i x}\right)$ received during unprotected population's exposure to the hazmat vapour cloud is calculated as follows:

$$
D_{i x} \approx \frac{10 \dot{m}_{L}}{v x^{0.88}} t
$$

Distance $h(m)$, at which unprotected population can receive the given inhalation dose $\left(D_{i x}\right)$ for the duration of exposure to hazmat cloud $t<t_{\max }$, can be approximately calculated as follows:

$$
x \approx\left(\frac{25 \dot{m}_{L} t}{v D_{i z}}\right)^{1.13} .
$$

The depth of secondary hazmat vapour cloud propagation $\left(L_{2}, m\right)$ is the distance from the point of origin of the primary cloud to the location where the unprotected population will receive the inhalation threshold dose $\left(P C t_{50}\right)$ during exposure, and it is calculated as follows:

$$
L_{2} \approx\left(\frac{25 \dot{m}_{L} t_{r}}{v P C t_{50}}\right)^{1.13}
$$

\section{CONCLUSION}

This paper explained the dispersion of vapours, gases and aerosols using several models according to the source of hazardous materials: instant point and volume source; instant linear source; continuous point and volume source; continuous linear source; continuous surface source; and combined source. The paper also provided an assessment of chemical accident parameters, as well as an assessment and prediction of parameters for each of the aforementioned sources of hazardous materials. 


\section{REFERENCES}

1. Voronjec, K., Obradović, N.,(1976). Mehanika fluida. Univerzitet uBeogradu, Beograd.

2. Arhipova, H. I., Kulıba, V. V. (1998). Upravlenie v črezvičapnŭh situacish. Moskva: RGGU.

3. Б. Обровић, Механика флуида, Универзитет у Каргујевцу, Машински факултет у Крагујевцу, 2007

4. Bogdanović, M. (1999). Opasnosti od hemijskih akcidenata [Chemical Accident Hazards]. Beograd: Zadužbina Andrejević.

5. Bursać, Ž.,Galović, I.,Hrvačić N. Kocijan S, Opasne tvari - mijere sigurnosti, sprečavanje, saniranje posljedica [Hazardous Materials - Safety Measures, Prevention and Mitigation], Zavod za općenarodnu odbranu i društvenu samozaštitu, SRH, Zagreb, 1990.

6. European Directive 96/82/CE - Seveso II.

7. Marković, D., Džarmati, Š., Gržetić, I., Veselinović, D. (1996). Fizičkohemijski osnovi zagitite životne sredine - izvori zagađivanja, posledice $i$ zaštita (knjiga II) [Physicochemical Fundamentals of Environmental Protection - Pollution Sources, Effects and Protection]. Beograd: Univerzitet u Beogradu.

8. Menьšikov, B. B., Švыrяev, A. A. (2003). Opasnble himičeskie obbekti i tehnogennnblŭ risk. Moskva: Gosudarstvennый Universitet imeni M.V. Lomonosova.

9. Cvetanović S., (2015). Integralni model sistemskog pristupa upravljanje rizikom od hemijskih udesa na lokalnom nivou, Doktorska disertacija, Niš.

\section{MODELIRANJE EFEKATA ISPUŠTANJA I ŠIRENJA GASOVA I PARA I AEROSOLA OPASNIH MATERIJA}

Modeliranje efekata ispuštanja i širenja gasova i para i aerosola opasnih materija se vrši: idealnim modelima koji pretpostavljaju da je površina horizontalnog preseka kontejnera (cisterne) konstantna, da se materije oslobađaju iz rupe u zidu, da se ne radi o dvofaznom sistemu i da nema otpora pri isticanju; realnim modelima koji uzimaju u obzir fenomen trenja; dvofaznim modelima koji uzimaju u obzir kvalitet i specifičnu zapreminu smeše pare i tečnosti; modelima koji uzimaju u obzir naglo oslobađanje tečnosti, gasova i para.

Ključne reči: izvor opasnih materija, hemijska kontaminacija, žarište udesa, hemijska situacija, procena i prognosa parametara izvora. 